専門医症例報告

\title{
義歯床形態に考慮を要した下顎歯肉・㚘粘膜癌切除後補綴症例
}

塙総司

\section{A Case of Postoperative Prosthodontic Reconstruction Considering Denture Base Form for a Resection of Lower Gingival and Buccal Mucosa Cancer}

\section{Soshi Hanawa}

抄 録

症例の概要：患者は 73 歳の女性で, 左側下顎骨辺縁切除術ならびに腹部全層植皮術後の下顎骨部分欠損 による植皮部陥凹部への食物の残椬を伴う咀嚼困難を主訴に来科した。ティッシュコンディッショナーを 用いて顎欠損部に対する義歯床辺縁・床翼部の形態形成を行ったうえで下顎顎義歯を製作した。

考察：機能時における煩粘膜と義歯床との間に緊密な接触が得られた結果，食物が植皮部の陥凹部に停滞 することは消失し，咀嚼機能が改善したと考えられる。

結論 : 植皮部の可動性が欠如している症例に対し, 適切な義歯床形態を付与することにより, 咀嚼機能を 改善し良好な経過を得ることができた。

和文キーワード

下顎頡義歯，咬合支持，ミリング，咀嚼機能，全層植皮術

\section{ABSTRACT}

Patient: A 73-year-old female patient who was undergoing marginal resection of the mandible for carcinoma and an abdominal full thickness skin graft complained of masticatory dysfunction with saburra in the mandibular recessed area. A mandibular denture for the defect was fabricated by using the tissue conditioner for molding the border and buccal flange of the denture.

Discussion: As a result of the attainment of close contacts between the buccal mucosa and buccal flange and the border of the denture base by using tissue conditioner, the saburra in the recessed area had disappeared and the masticatory function had improved.

Conclusion: With the lack of mobility of the skin graft, forming an appropriate shape of the flange and border of the denture base achieved improvement of the masticatory function and favorable prognosis.

\section{Key words}

mandibular denture for defect, occlusal support, milling, masticatory function, full thickness skin graft 


\section{I 。緒言}

悪性腫瘍切除後の口腔粘膜，顎堤および顎骨の変形や 欠損を伴う症例の義歯補経治療に際しては，欠損部の義 歯床形態と咀嚼・発音・嚥下などの機能との調和を図る ことが肝要である. 今回，下顎歯肉・㚘粘膜癌切除後の 患者に対して，これらの点への配慮のもと，可撤性部分 床義歯を用いて補綴処置を行つた症例について報告する。

\section{II．症例の概要}

患者: 73 歳 (初診当時), 女性.

初診：2006 年 7 月 12 日.

主訴：歯の欠損および顎欠損による咀嚼困難.

既往歴：全身的には特記事項なし。

現病歴 : 2005 年 9 月 27 日, 近隣歯科医院にて歯周 治療を受けた。同日就寝前に左側煩粘膜に違和感を覚 え，翌日に紹介により某病院を受診したところ，本院口 腔外科での精査・加療を锥められ同日 28 日に本院口腔 外科を受診. 10 月 4 日に左側煩粘膜扁平上皮癌(T2 N0 M0）（図 1，2）と診断され，10 月 13 日に左側煩粘膜, 歯肉，および煩側歯槽骨を部分切除され，腹部全層植皮 術を施行された。 なお，放射線療法は行っていない。 2006 年 6 月 20 日に欠損部および顎欠損による咀嚼困 難を訴え当科受診となった。

現症：当科初診時，残存歯数 24 本，ケネディー分類 I 級，アイヒナー分類 B2，7|567 欠損および $\longdiv { 5 6 7 }$ 部の㚘側に下顎骨辺緑欠損が認められた。 34 にはテ レスコープの内冠が装着されていた (図 3)。咬合高径, 咬合平面，下顎位，咬合位に異常は認められなかった。 7|34567 における咬合支持の欠如，植皮部におけ る可動性の欠如，植皮部の陥凹部への食物の停滞が原因 と考えられる咀嚼困難か認められた。

検査結果：エックス線所見では，歯槽骨において全顎 的に著しい骨吸収は認められず，腫瘍切除部の骨辺縁は 境界明膫であった（図 4).

診断: $7 \mid 567$ 欠損および顎欠損による咀嚼障害.

\section{III．治療内容と経過}

\section{1. 治療方針}

義歯非装着時における咬頭嵌合位の安定を図るため, $\longdiv { 3 4 }$ に固定性の歯冠補綴装置を装着することとした。 また，義歯の支持・把持・維持力の向上，舌感の向上を 図るため, $\longdiv { 3 4 }$ にミリング処理を施した歯冠補綴装置

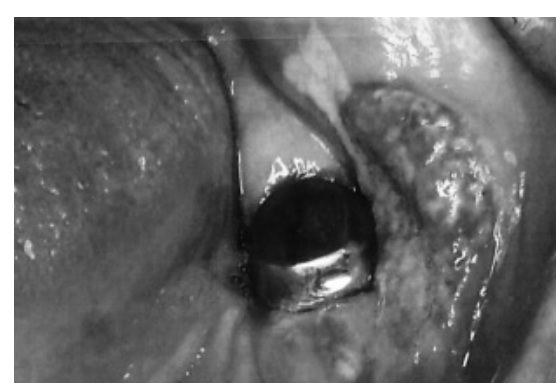

図 1 Lower left gingival and buccal mucosa cancer 下顎左側歯肉・煩粘膜癌

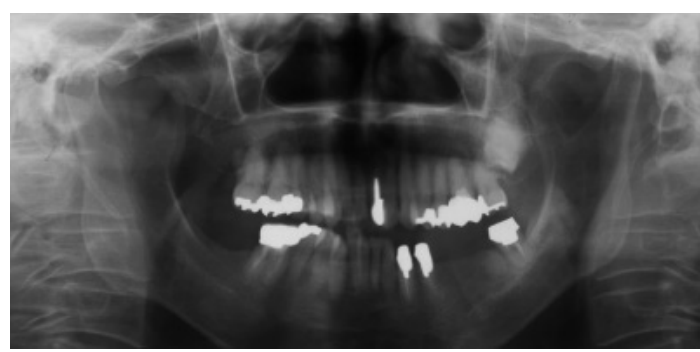

図 2 Panoramic radiograph at first examination 初診時のパノラマX X 線写真
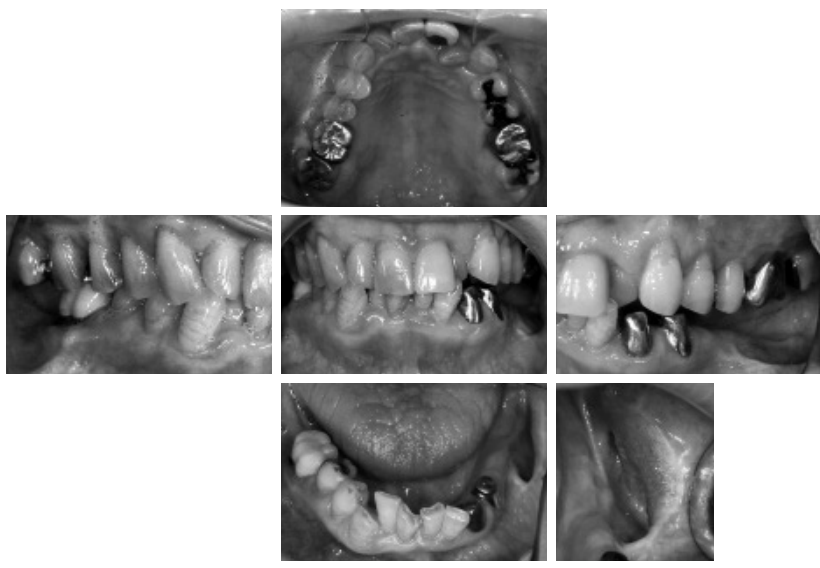

図 3 Intraoral views at first examination and previous denture

初診時の口腔内写真および旧義歯

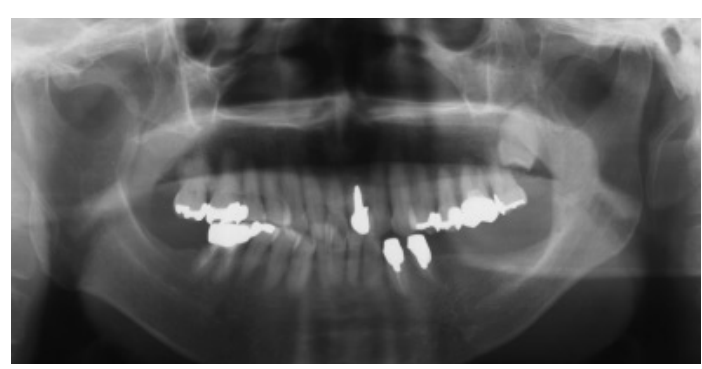

図 4 Panoramic radiograph at examination after surgery 術後のパノラマX $\mathrm{X}$ 線写真 

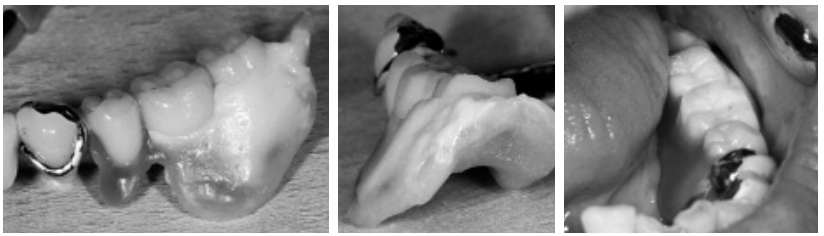

図 5 Buccal flange and border molding by using tissue conditioner

ティッシュコンディッショナーによる義歯床翼部お よび床縁部形成

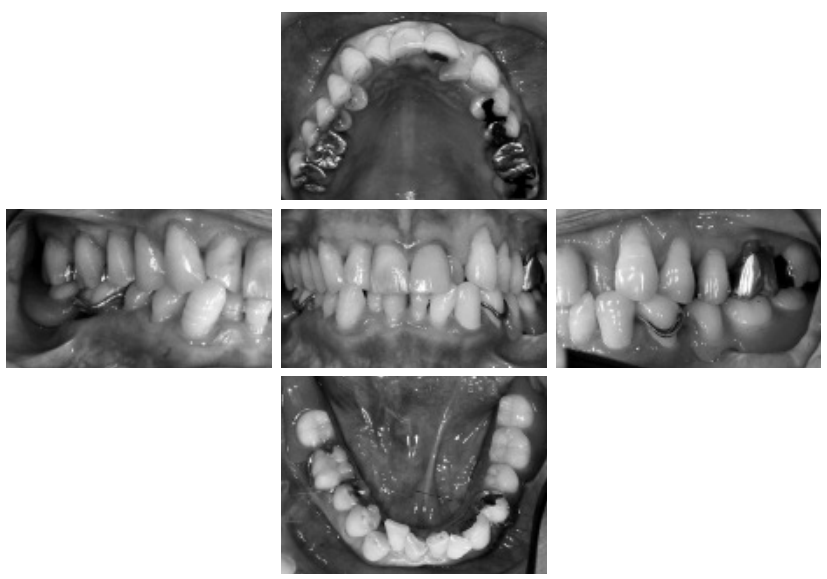

図 6 Intraoral views at completion of prosthetic treatment

補綴治療終了時の口腔内写真
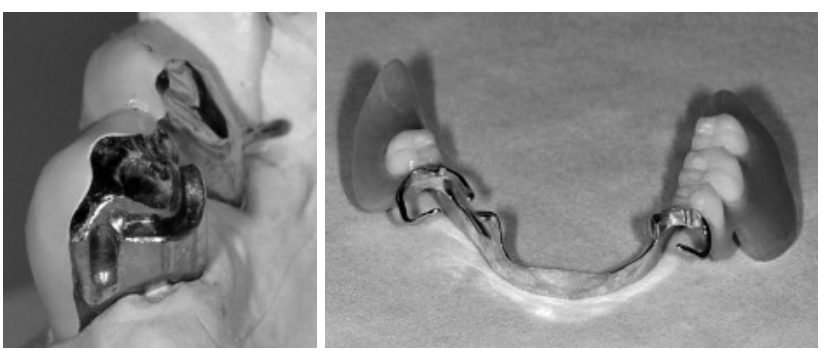

図 7 Porcelain-fused-to-metal restorations and lower definitive denture for defect

陶材焼付鋳造冠と最終義歯

を装着後，両側性処理の金属床義歯を装着することとし た。さらに， 34 を連結することにより支台歯への荷 重の分散を図ることとした。㚘棚部は皮質骨を一部切除 されたものの歯肉煩移行部付近まで連続的に存在してい たので，この部位で咬合力を十分に負担できるものとみ なし，通常の可撤性部分床義歯に準じた咬合を付与し， 歯根膜だけでなく粘膜負担も期待した。植皮部の可動性 の欠如による陥凹部への食物の停滞に対しては，ティッ シュコンディッショナーを用いて動的印象を行い義歯床 辺緑部・床翼部の形態を決定することとした。

\section{2. 治療内容}

2006 年 7 月 12 日から当科における治療が開始と なった. 7 月 12 日: 各種資料採得を行った. 8 月 25 日: 34 のテレスコープの内冠を除去し, 支台歯形成 を行い，暫間被覆冠を仮着した。10月 18 日: 34 印 象採得を行った。10月 24 日：咬合床を用いて 34 の 咬合採得を行った。11月 15 日: 34 に陶材焼付鋳造 連結冠を試啇し， $7 \mid 567$ 部の筋圧形成を行い，咬合 採得およびピックアップ印象を行った。 12 月 13 日： 白金加金合金製のメタルフレームの試適を行ったが，ミ リング部の維持力が強く患者が着脱困難を訴えたため維 持力の調整後に再度フレームの試適を行うこととした。 2007 年 1 月 18 日：メタルフレームの再試適および蝋 義歯の試適を行った.この際, 顎欠損部の義歯床辺縁部 ・ 床翼部にティッシュコンディッショナーを添加し, 患者 に発音，咀嚼，嚥下，下顎運動等の機能的運動を行わせ 義歯床形態を決定した (図 5)。2 月 15 日: 34 陶材 焼付鋳造冠および $7 \mid 567$ 義歯を装着した(図 6,7).

\section{3，治療経過}

2007 年 2 月の最終補綴終了後, 3 年 7 カ月が経過 している (図 8，9). 義歯装着後は, 1 力月に 1 回のメ インテナンスを行い経過は良好であった。しかし, 2009 年 7 月, 6 の煩側クラスプ銁尖部に破折が認められた. 義歯の維持力を確保するために, 6 陶材焼付鋳造冠の 鉤尖相当部にディンプルを形成し，鉤尖部を屈曲して対 応した. 2010 年 4 月, 1 切縁のレジン充填部位に破 折が認められた。う蝕処置, 歯周治療は近隣歯科医院に て 1 カ月に 1 回のメインテナンスを行っていたため 1 の切縁部は近隣歯科医院にてレジン充填が行われた。 そ の後も 1 カ月ごとのリコールを行っているが，最終義 歯装着後は植皮部に食物が停滞することや植皮部を咬ん でしまうこともなく，義歯床翼・床縁部の形態調整は装 着後には行っていない. 患者の満足度は高く, 義歯の維 持力の低下，動摇，破損等もなく良好に経過している.

\section{4. 機能評価}

本症例において, 顎義歯の咀嚼能力を主観的評価とし て平井らの 35 品目の食品アンケート調査による咀嚼ス コアを用いて評価を行った ${ }^{1)}$ 。また，ピーナッツ 3 個 を片側咀嚼させたときの咀嚼開始から嚥下終了までの時 間を計測することにより咀嚼能力の客観的評価を行っ た。咀嚼スコアは，義歯非装着時は 89.3，義歯装着時 も 89.3 と同じスコアとなり高い值を示した。咀嚼・嚥 下時間は，義歯非装着時においては左側で 172 秒，右 側で 119 秒となり，義歯装着時においては左側で 86 


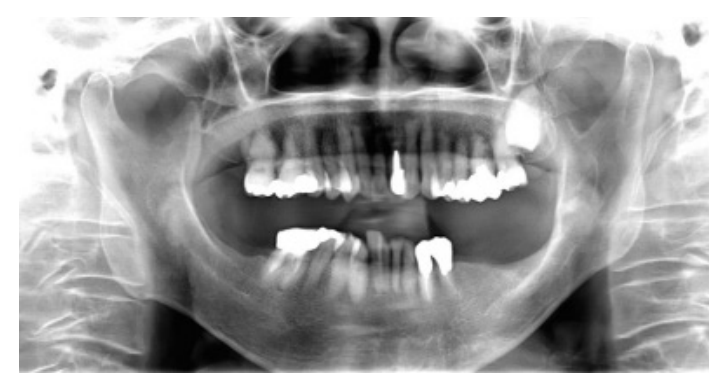

図 8 Panoramic radiograph at 3 years after prosthetic treatment

補綴治療終了後 3 年経過時のパノラマX $\mathrm{X}$ 線写真

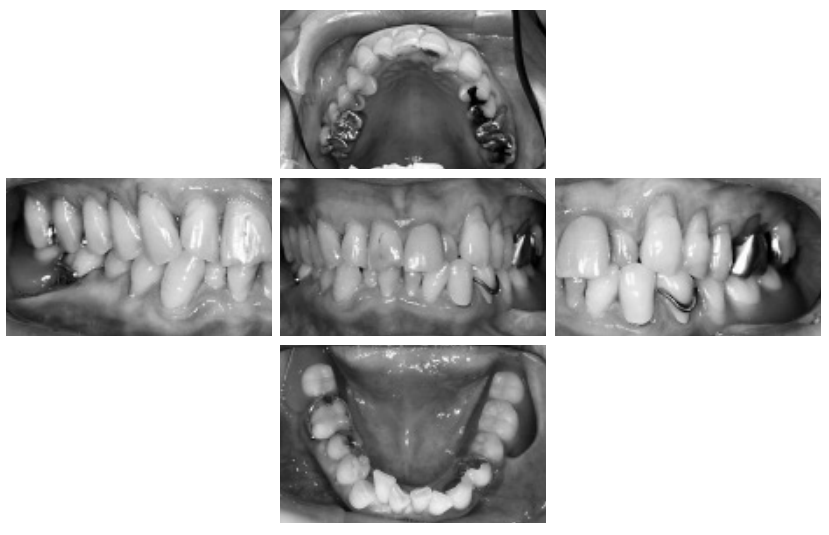

図 9 Intraoral views at 3 years after prosthetic treatment

補綴治療終了後 3 年経過時の口腔内写真

秒，右側で 88 秒となり，両側において義歯を装着する ことにより咀嚼・與下時間の減少が認められた。

\section{IV. 考 察}

本症例は，下顎左側顎欠損部の煩側前庭部が食物の停 滞が生じやすい深く陥凹した形態を有しており，また植 皮による再建のため煩部の可動性がそしかったため，義 歯床辺縁形態のみならず床翼形態の決定に考慮を要し た，通常の筋圧形成および印象採得により，顎欠損部の 義歯床辺縁形態を得ることはできるが，人工歯歯頝部付 近における適切な床翼形態を得ることは困難であり，た とえ印象採得ができたとしても作業模型の製作が困難と なる。 そこで，義歯床翼形態を決定するために，䑺義歯 試適時に人工歯歯頝部付近までティッシュコンディッシ ヨナーを添加し, 最大開口運動および機能運動時におけ る煩部の形態を動的に採得した，義歯装着後は，煩側前 庭部に食物が停滞することや咬煩も認められず，装着後 に義歯床の形態修正を行うことはなかった.

義歯非装着時，装着時の咀嚼スコアは同じスコアであ
り高い值を示した。この原因として，右側の欠損が $\overline{7}$ の 1 歯のみであり, 咀嚼を営むのには十分な咬合支持 が確保されているためと考えられる。一方で，咀嚼開始 から嚥下終了までの時間は義歯装着により短くなった。 過去の研究において, 咀嚼機能が低下すると咀嚼時間や 咀嚼回数を増加させて機能の低下に対応することか報告 されている ${ }^{2-4)}$. 本症例でも同様に，歯の欠損および顎 堤の欠損により咀嚼機能が低下し, 有歯顎時と比較して 咀嚼時間が延長していたのではないかと推察できる。ま た金田ら ${ }^{5)}$ は，片側遊離端義歯の装着は，食物の粉砕 自体に大きな貢献をしないが，固有口腔を確立し食物を 舌側へ集積する役割を果たしていると報告している。本 症例においては，義歯を装着することにより咀嚼開始か ら嚥下終了までの時間が短くなった。これは，本症例は 両側遊離端欠損ではあるが，金田らの報告と同様，義歯 の装着による固有口腔の確立が燕下機能の回復に寄与し たものと考えられた。

\section{V. 結 論}

下顎歯肉・煩粘膜癌切除後の患者に対して, 適切な義 歯床形態を付与した下顎䫈義歯を装着したことにより咀 嚼機能の回復を図り，良好な結果を得た。

\section{文献}

1) 平井敏博, 安斎 隆, 金田 洌, 又井直也, 田中 收, 池田和博ほか．摂取可能食品アンケートを用いた全部床 義歯装着者用咀嚼機能判定表の試作。補綴誌 1988; 32: 1261-1267.

2) Feldman RS, Kapur KK, Alman JE, Chauncey HH. Aging and mastication: Changes in performance and in the swallowing threshold with natural dentition. J Am Geriatr Soc 1980; 28: 97-103.

3) Mioche L, Bourdiol P, Monier S, Martin JF, Cormier D. Changes in jaw muscles activity with age: Effects on food bolus properties. Physiol Behav 2004; 82: 621627.

4）小城明子，柳沢幸江，植松 宏。咀嚼回数による摂食機 能評価方法の検討一評価への嚥下間值の影響一。摂食 燕下リ八会誌 2006; 10:231-238.

5）金田 恒，河野正司．片側遊離端義歯装着の意義。新潟 歯学会誌 2000; 30: 85-86.

著者連絡先 : 塙 総司

干980-8575 宮城県仙台市青葉区星陵町 4-1

Tel: 022-717-8369/8370

Fax: 022-717-8371

E-mail: s-hanawa@m.tohoku.ac.jp 